\title{
Comparing different sampling methods in order to reconstruct plant economies at the Eneolithic lake dwelling site Stare gmajne, Slovenia
}

\author{
Tjaša Tolar, Anton Velušček \\ ZRC SAZU, Institute of Archaeology, Ljubljana, SI \\ tjasa.tolar@zrc-sazu.si
}

\begin{abstract}
The results of plant macroremains studies of the Eneolithic (c. 3160-3100 cal BC) lakeshore settlement at Stare gmajne on the Ljubljansko barje in Slovenia are presented. Archaeobotanical material was collected in two different ways: (1) systematic surface sampling from the cultural layer, and (2) judgement sampling from an incompletely burnt large loom-weight. The preservation state and the spectra of plant macroremains were different in both types of samples. The first study primarily deals with the waterlogged plant remains of various types and taxa, while the second deals with carbonised and half-carbonised cereal macroremains, mostly chaff. Both studies confirm the cultivation of main crops: emmer, einkorn and barley.

IZVLEČEK - Predstavljeni so rezultati analiz rastlinskih makroostankov z eneolitskega (ok. 31603100 cal BC) kolišča Stare gmajne z Ljubljanskega barja, Slovenija. Material za arheobotanične raziskave smo pridobili po dveh metodah: (1) sistematično površinsko vzorčenje iz kulturne plasti in (2) vzorčenje po presoji iz nepopolno žgane velike glinene uteži. Ohranjenost in spekter rastlinskih makroostankov iz obeh vzorcev se bistveno razlikujeta. Prva študija se ukvarja predvsem z ne-zoglenelimi in z vodo prepojenimi makroostanki različnih tipov in taksonov, medtem ko druga proučuje v glavnem zoglenele in pol-zoglenele ostanke žit, predvsem plev. Obe študiji potrjujeta gojenje glavnih kulturnih rastlin: dvozrnice, enozrnice in ječmena.
\end{abstract}

KEY WORDS - Eneolithic; pile dwelling; Slovenia; plant economy; taphonomy

\section{Introduction}

The Stare gmajne site is an Eneolithic (Copper Age) pile dwelling site in Slovenia dated to the $4^{\text {th }}$ millennium BC. According to dendrochronological and radiocarbon dating, it was settled many times ( $\breve{C} u$ far et al. 2015). The earliest settlement ended before $3300 \mathrm{cal} \mathrm{BC}$, and the latest around $3110 \mathrm{cal} \mathrm{BC}$ (Čufar et al. 2009; 2010; 2015). The site became more widely known when a wooden wheel with an axle, the oldest found to date, was discovered in 2002. Taking into account its radiocarbon dating and the age of the settlement where it was found, it is c. 5150 years old (Velušček et al. 2009). In 2006 and 2007 , the site was excavated; two $15 \mathrm{~m}^{2}$ trenches (Velušček 2009.54-55) were opened and researched in detail (see Velušček 2009).
During the excavation in 2006, a large loom-weight was found in the latest settlement phase, which is dendrochronologically dated to between 3160 and $3100 \pm 14$ cal BC. The bottom of the loom-weight was accidentally broken or fell off during the excavation. It was carefully stored as a judgement sample for analysis in the lab. Waterlogged clayey material was obtained from the interior of the broken loom-weight and analysed in detail (Tolar et al. 2016).

In 2007, for the first time in Slovenia, excavations included appropriate sampling and treatment methods for archaeobotanical investigations of waterlogged material (Tolar et al. 2010). Three $1 \mathrm{~m}^{2}$ qua- 
drants from the $15 \mathrm{~m}^{2}$ trench with an approx. $46 \mathrm{~cm}$ thick cultural layer were systematically surface sampled and archaeobotanicaly analysed (Fig. 1). Both the latest (upper $21 \mathrm{~cm}$ of the sediment in the cultural layer) and the earliest (lower $25 \mathrm{~cm}$ of the sediment) settlement phases were investigated (Tolar et al. 2011).

The present paper compares these two studies: surface sampled sediment samples from the latest cultural layer of the excavated trench in $2007 v s$. judgement sampled material from the loom-weight. Both samples were waterlogged and therefore had great potential for archaeobotanical investigation. There are also important differences between the two. Although preserved in waterlogged conditions, the first study deals mainly with waterlogged plant macroremains that were deposited on the surface during the life of the settlement, while the second deals mainly with carbonised plant macroremains that were intentionally added by the dwellers to reinforce the large clayey object. Comparing plant remains that were preserved under various taphonomic conditions and collected by different sampling methods is important, because they can present different sources of evidence (Jones 1991; Tolar 2016. $46,56-59,62-65,142-148,166)$.

\section{Material and methods}

Two methodologically different archaeobotanical investigations from the same archaeological site (i.e. Stare gmajne) and period (the latest settlement phase) are presented and compared. The first includes an analysis of the surface sediment samples taken systematically from the trench excavated in 2007. The second includes an investigation of the material from the broken loom-weight, called judgement sampling. Therefore, two sampling methods, surface and judgement (see e.g., Jacomet, Kreuz 1999; Tolar 2016.62-65) were applied and compared.

\section{Surface sampling from the trench}

From the Stare gmajne trench in 2007 (Fig. 1) surface sediment samples of approx. 1 litre of sediment per 1 depth/cut (see Fig. 1b) from the cultural layer were collected. Horizontally, it was sampled from three randomly chosen square metres (i.e. quadrants 1,9 and 13) (Fig. 1a).

The $46 \mathrm{~cm}$ thick cultural layer was divided vertically into 8 depths/cuts of approx. $5 \mathrm{~cm}$ (Fig. 1b). Depths/ cuts 4 and 5 pertain to the latest (i.e. the youngest) settlement phase, while depths/cuts 7 and 8 pertain to the earliest (i.e. the oldest) phase.

Altogether, 15 samples with a total volume of some 9 litres were analysed. The samples were first washed and wet sieved, as proposed for waterlogged sediments (see e.g., Hosch, Zibulski 2003; Tolar et al. 2010). Sieves with $2 \mathrm{~mm}$ and $0.355 \mathrm{~mm}$ mesh sizes were used. The collected waterlogged organic fractions were stored (and kept) in water and at low temperatures. Prior to the analysis, random sub-sampling was necessary, especially of the small (i.e. $0.355 \mathrm{~mm}$ ) fractions, because the samples were very rich in macroremains. In addition to whole seeds/ fruits and grains, grain fragments with embryo ends, glume bases, rachis fragments, fragments of seeds/ fruits with the base and flax (Linum) capsule fragments with a tip larger than $3 \mathrm{~mm}$ were sorted out and counted. A Leica MZ75 stereomicroscope with 6.3 up to 50 magnification was used for the examination. For identification, the reference collections of IPAS, Basel and Institute of Archaeology ZRC SAZU, as well as special literature (Berggren 1969; 1981; Anderberg 1994; Cappers et al. 2006; Jacomet 2006) were consulted.

\section{Judgement sampling from the loom-weight}

A special and very important find, a loom-weight $22.5 \mathrm{~cm}$ high and $14.4 \mathrm{~cm}$ wide, was discovered in 2006. During the excavations, the bottom of the a

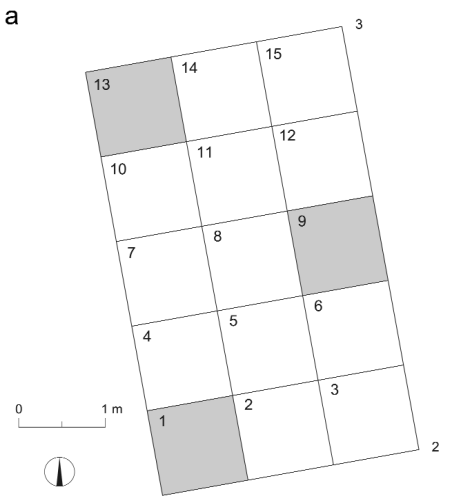

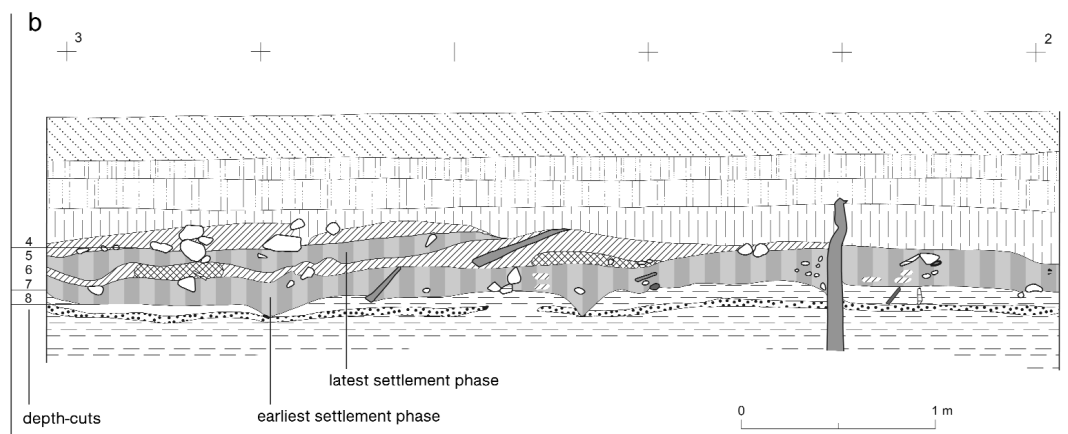

Fig. 1. The trench in 2007. a horizontally and b vertically (drawing T. Korošec). 
weight broke off and its incompletely burnt, clayey and waterlogged interior became visible. Its outer parts were burnt, but the interior was full of waterlogged clayey material (Fig. 2) - original material for making larger clayey objects.

The inner, clayey and waterlogged parts were removed from the weight (Fig. 2b). In total, almost 1 litre of clayey sediment was obtained and analysed. It was very carefully wet sieved through two sieves with standard mesh sizes ( 2 and $0.355 \mathrm{~mm}$ ). Both organic fractions were wet stored and examined under a stereomicroscope at up to 50 magnification(s). Identifications, type of remains, state of preservation and counts were noted. A careful morphological study of different cereals remains (mainly chaff) was made and the proportions of different cereal types and crop species were calculated. Based on this, an estimate of the clay-straw ratio used for making the clayey objects was made (Tolar et al. 2016).

The main aim of the present paper is to summarise and compare the archaeobotanical results from two contexts (surface sampling from the trench and judgement sampling from the loom-weight) from the same site and period (i.e. the latest phase of pile dwelling site Stare gmajne, dendro dated to $c$. 3160$3100 \pm 14$ cal BC) in order to reconstruct the plant economy at the site, especially of cereals.

\section{Results}

\section{Surface sampling from the latest cultural layer of the Stare gmajne site}

The concentrations of the identified plant macroremains averaged 1572 remains per 1 litre of sediment; $95.4 \%$ of the identifiable plant macroremains were preserved in an uncarbonised state, i.e. waterlogged.

A total of 38 taxa were identified, 5 of which were cultivated: emmer (Triticum dicoccum), einkorn (Triticum monococcum), barley (Hordeum vulgare), poppy (Papaver somniferum), and flax (Linum usitatissimum) (Fig. 3). While the remains of poppy and flax were mainly represented by the remains of seeds/fruits (e.g., Figs. 3d, e), the cereal macroremains were mainly represented by chaff remains (e.g., Figs. 3a-c). Only 8 cereal grains (of all three taxa) were sorted out. The concentrations of cereal chaff remains (129 per 1 litre of sediment) are normal for waterlogged cultural layers (or even lower; e.g., for the earliest settlement phase of Stare gmajne site, the average concentration of cereal macro-

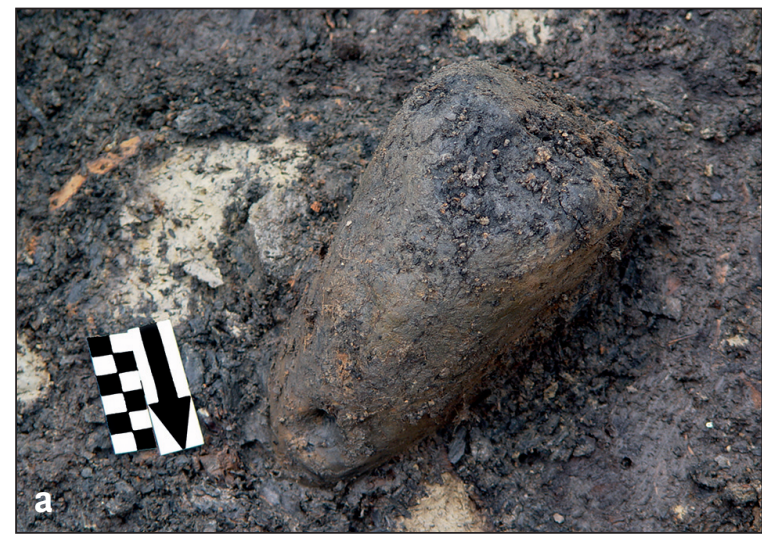

b

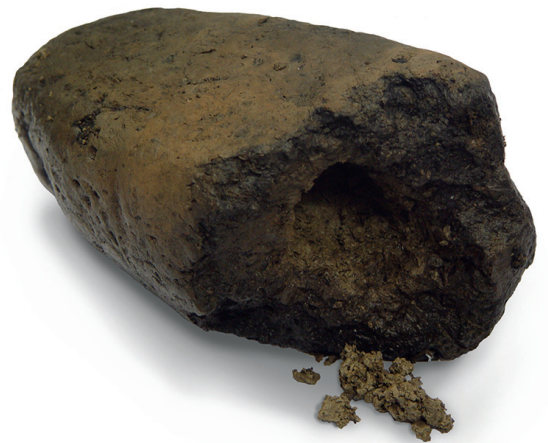

Fig. 2. Incompletely burnt pyramid-shaped $1.5 \mathrm{~kg}$ heavy clayey loom-weight was $22.2 \mathrm{~cm}$ high and up to $14.4 \mathrm{~cm}$ wide. During excavations (a) and during cleaning in the lab (b) (photo a M. Turk and b T. Tolar).

remains is 652). They comprise general waste around the site and are therefore not concentrated in a particular feature.

Another 7 taxa were presumably collected for human consumption: turnip (Brassica rapa), acorn (Quercus sp.), hazelnut (Corylus avellana), water chestnut (Trapa natans), apple/pear (Maloideae), strawberry (Fragaria vesca), and blackberry (Rubus fruticosus).

Surface sediment samples also include the remains of the wild (i.e. not nutritive) plant taxa: 4 water plants, 9 lakeshore plants, 6 field weed and ruderal plants, 6 woodland plants, which give an insight into the ecological conditions at the site in the time of the pile dwellers. The settlement was located near the lake; the dwellers also exploited the surrounding woodland for pasturing, gathering and tree felling (for details from both the latest and the earliest settlement phases, see Tolar et al. 2011).

\section{Judgement sampling from the Stare gmajne loom-weight}

The density of botanical macroremains was high: in the less than 1 litre of clayey material obtained 
from the loom-weight, a total of 1950 identifiable plant macroremains were sorted and counted. They were all preserved in a carbonised or semi-carbonised state. Among them, more than 1800 very well preserved and easily identifiable cereal by-products, i.e. chaff (Fig. 4) and 22 cereal grains were identified. The clay-organic material (mainly chaff) ratio was easily determined. It is at least 93:7 (i.e. 93\% of clayey material and at least $7 \%$ of cereal by-products) (for details, see Tolar et al. 2016).

As well as 3 cereal taxa, emmer (Triticum dicoccum), einkorn (Triticum monococcum) and barley (Hordeum vulgare), another 9 taxa were identified: poppy (Papaver somniferum), oak (Quercus sp.), brome grass (Bromus sp.), grasses (Poaceae), cf.
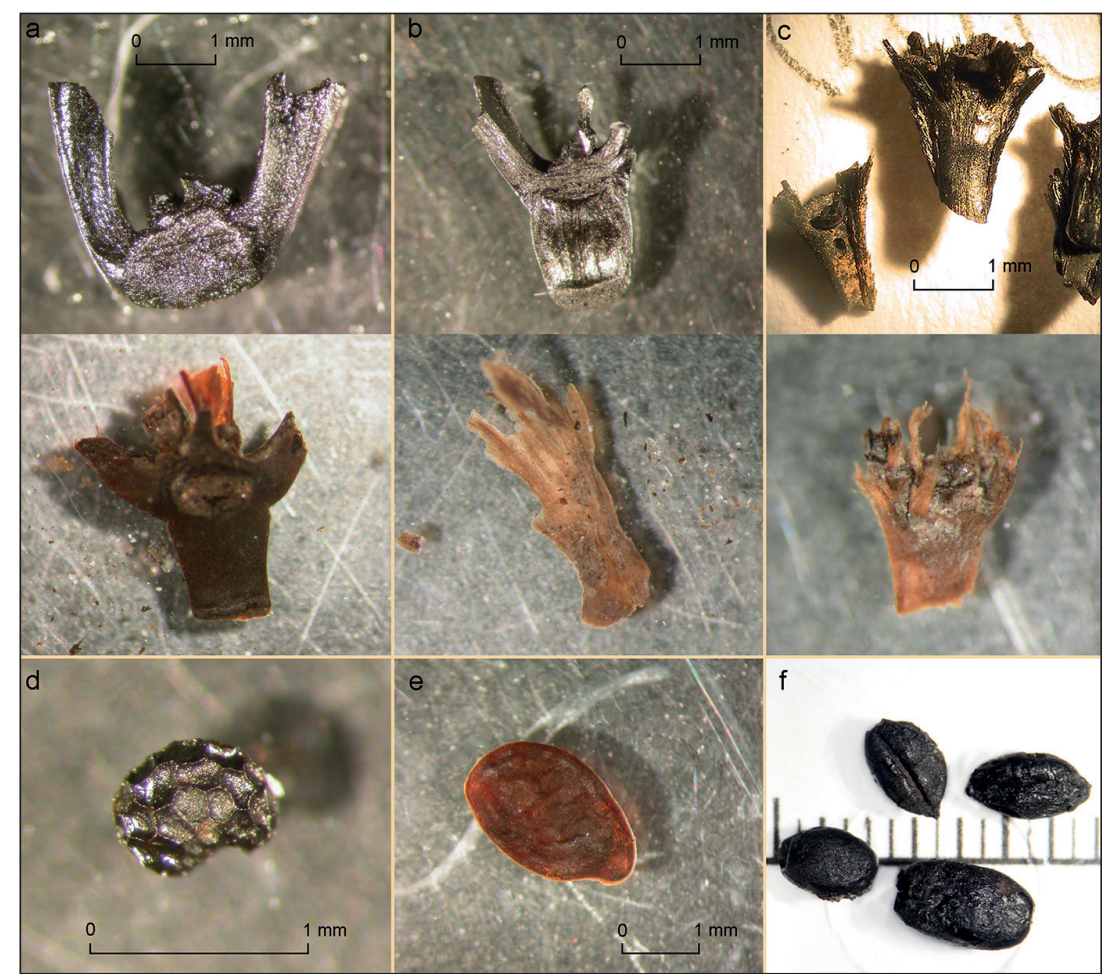

Fig. 3. The most important cultivar macroremains from the Stare gmajne site, surface sampling: a emmer spikelet fork carbonised and uncarbonised; b einkorn spikelet fork carbonised and uncarbonised glume base; c barley rachis fragments carbonised and uncarbonised; d uncarbonised poppy seed; e uncarbonised flax seed; f carbonised barley grains (photos a-e T. Tolar, f D. Valoh). millet (Panicum miliaceum),

sedges (Cyperaceae), goosefoot (Chenopodium album), moth mullein (Verbascum blattaria), and St John's wort (Hypericum perforatum). In total, the 64 seeds/fruits of these 'non-cereal' taxa are not representative enough to enable interpretation of the gathering economy or ecological conditions at the site.

An experiment was conducted to learn why different processes occurred when the plant remains were deposited in the loom-weight, i.e. mostly carbonised in waterlogged clayey material. Dry plant material (hay) was added to the clay from which two objects shaped similarly to the Stare gmajne loom-weight were made. As well as tempering, it became clear that the added plant material allowed very fine and easier moulding and forming of the raw clay. Two objects were made, each of them burnt (baked) on an open fire with hot coals for different times. The added plant remains in the object that was burnt for a longer time (i.e. 3 hours and 35 minutes) were completely charred and highly reduced, while the plant remains in the second (that was burnt for 2 hours less) were differently preserved, i.e. mostly in a carbonised and semi-carbonised state, and some not carbonised.

\section{Discussion}

Comparison between the surface and judgement sampled material

Although in both cases of sampling, the researched material was waterlogged and clayey, the state of

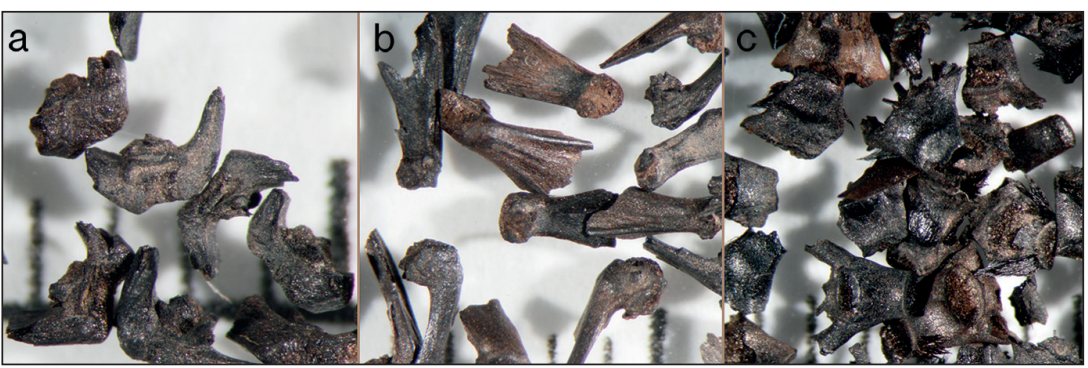

Fig. 4. Most frequent macroremains from the loom-weight cereal by-products. a emmer spikelet forks; b glume bases; c barley rachis fragments (photo D. Valoh). 
preservation of the plant macroremains between the two compared contexts varies. Some $95.4 \%$ of macroremains from the surface cultural layer were preserved in an uncarbonised, i.e. waterlogged state (Fig. 3), while the plant remains from the loomweight are all preserved in carbonised $(71 \%)$ or at least in a semi-carbonised (29\%) state (Fig. 4).

Table 1 presents some basic differences between the surface (S) and the judgement (J) sampled material. Lower concentration of plant macroremains in the sediment samples from the cultural layer ( $\mathrm{S}$ in Tab. 1) in comparison to the judgement sampled material from the loom-weight ( $\mathrm{J}$ in Tab. 1) is evidence of intentionally added (or used) plant macroremains (especially of cereals) in the judgement sample. Evidently, the greater diversity of plant taxa in the surface samples in comparison to the judgement sample additionally indicates the intentional use of carefully selected cereal by-products for tempering the large clayey object.

The plant spectra between the compared contexts differs considerably. Samples from the cultural layer contain remains of diverse plants (38 taxa altogether: cultivated, gathered and wild). Most of the remains are not carbonised, i.e. waterlogged. On the other hand, the sample from the loom-weight consists mainly (96\%) of 3 cultivar species: emmer, einkorn and barley, preserved in a semi-carbonised or fully carbonised state; these macroremains (especially chaff) were intentionally added to the clay in order to obtain well-tempered material for making quite a large loom-weight.

As the judgement sampled material contains evidently carefully selected and charred cereal by-products, the only possible comparison between the two differently sampled and preserved materials is the importance of cereal species for the plant economy at the Stare gmajne site. Despite the different preservation conditions (waterlogged $v s$. charred) in both samples (surface and judgement) cereal by-products (i.e. chaff) prevail over cereal grains. Therefore, the grain units (i.e. 1 grain $=1$ spikelet fork $=2$ glume bases $=1$ barley rachis frg.) in 1 litre of sediment sample of both investigated materials (surface-S and judgement-J) were compared (Tab. 2). The only difference between the two is the preservation state: sur- face - waterlogged chaff $v$ s. judgement - charred chaff.

Cereal macroremains (especially by-products) are obviously concentrated in the material from the loom- weight (1412-J : 526-S). It seems that the proportions of glume wheat-GW (i.e. emmer and einkorn) remains in the loom-weight are higher than those of barley rachis fragments-B (949-GW : 463-B). In contrast, barley grain units in the wet soil surface samples from the cultural layer prevail over glume wheat grain units (387-B : 139-GW). Was barley more a popular crop species than glume wheats? Did the inhabitants deliberately choose glume wheat by-products (although they were in a minority) for tempering?

Data from a single loom-weight and the only and first appropriately investigated surface sediment samples from Slovenian pile-dwelling sites are not sufficient for definite conclusions. More archaeobotanical studies at Ljubljansko barje pile-dwelling sites should be made to answer the two questions posed above. At the moment, we can only assume that different taphonomical processes are the most likely principal reason for such a result. Carbonised plant material from the loom-weight could contain more glume wheat by-products (i.e. glume bases and spikelet forks of emmer and einkorn) merely because of the taphonomy. The inhabitants may have simply used the available chaff without selection, but differential carbonisation and destruction rates of different plant types (e.g., Bowman 1966; Hillman 1981; Boardman, Jones 1990; see also experimental work in this paper and Tolar et al. 2016) that were added to the clay may have played the main role. This could be one of the reasons for the higher proportions of glume wheat over barley byproducts preserved in the incompletely burnt loomweight.

\section{Tempering with plant macroremains}

The clay which was used by the dwellers to make the weight was tempered with probably uncarbo-

\begin{tabular}{|c|c|c|c|c|c|c|c|}
\hline $\begin{array}{c}\text { vol. of the } \\
\text { sediment } \\
(\mathrm{ml})\end{array}$ & $\begin{array}{c}\text { vol. of organic } \\
\text { fractions } \\
(\mathrm{ml})\end{array}$ & $\begin{array}{c}\text { no. of } \\
\text { ident. plant } \\
\text { remains }\end{array}$ & $\begin{array}{c}\text { conc. per } \\
\text { l litre of } \\
\text { sediment }\end{array}$ & $\begin{array}{c}\text { no. of } \\
\text { cultivar } \\
\text { taxa }\end{array}$ & $\begin{array}{c}\text { no. of } \\
\text { gathered } \\
\text { taxa }\end{array}$ & $\begin{array}{c}\text { conc. of } \\
\text { cultivar } \\
\text { remains }\end{array}$ \\
\hline $\mathrm{S}$ & 3200 & 420 & 1583 & 495 & 5 & 7 & 141 \\
\hline $\mathrm{S}$ & $<1000$ & 65 & 1950 & $>1950$ & 4 & 1 & $>1875$ \\
\hline
\end{tabular}

Tab. 1. Some of the basic archaeobotanical results for surface sediment samples S and judgement sample from the loom-weight- J. Both sediments were waterlogged preserved and represent the same site and period (latest settlement phase). 
nised cereal chaff to reinforce it (the experimental work in this paper confirms this). It has already been proven that tempering was practised, not necessarily for loom-weights, at earlier settlements throughout Europe (e.g., Hopf 1977; 1980; Borojević 2006; Henn et al. 2015). Ethnographic evidence from presentday societies as well as the archaeobotanical evidence of past societies indicate that by-products produced during cereal processing (i.e. chaff, straw and weed seeds, as well as some

\begin{tabular}{|l|c|c|c|c|c|}
\hline $\begin{array}{c}\text { emmer } \\
\text { (Triticum } \\
\text { dicoccum) }\end{array}$ & $\begin{array}{c}\text { einkorn } \\
\text { (Triticum } \\
\text { monococcum) }\end{array}$ & $\begin{array}{c}\text { emmer/einkorn } \\
\text { (Triticum } \\
\text { di/monococcum) }\end{array}$ & $\begin{array}{c}\text { barley } \\
\text { (Hordeum } \\
\text { vulgare) }\end{array}$ & Total \\
\hline $\mathrm{S}$ & 67 & 72 & 274 & 387 & 526 \\
\hline $\mathrm{J}$ & 482 & 193 & 463 & 1412 \\
\hline
\end{tabular}

Tab. 2. Numbers (concentrations) of grain units in 1 litre of sediment for 3 cereal taxa. S surface samples from the cultural layer in which uncarbonised cereal chaff predominate; J judgement sample from the loom-weight in which carbonised cereal chaff predominate. grains; e.g., Hillman 1981; 1984a) were used as fuel, fodder or temper (Watson 1979; van der Veen 1999; Henn et al. 2015). Examples of the use of cereal byproducts for tempering in the late Neolithic have been found in plant impressions at many European sites (e.g., Hopf 1977; 1980; Bakels 1984; Borojevic 2006). Imprints of wheat chaff and culm fragments of wild grasses on daub and ceramics (e.g., KohlerSchneider 2007; Borojević 2006) are proof of this. It is very difficult both to precisely identify the plant material used and define its proportions, since there are no techniques to identify the actual quantity of straw and chaff used, because plant remains or even just their imprints are preserved in burnt and dried pottery or daub (Henn et al. 2015). Many attempts have been made to calculate this ratio (Ginder 1996; Borojević 2006; Henn et al. 2015), but the results have never been straightforward. The unburnt original material for making the clayey object from the Stare gmajne site gives us an opportunity to calculate this ratio. In less than 1 litre of waterlogged sediment from the loom-weight, $65 \mathrm{ml}$ of organic fractions, mainly cereal by-products, were caught in the sieves. Some 1950 plant macroremains were sorted, identified and counted. Cereal by-products of barley, emmer and einkorn predominate; in total, 1412 grain units were counted. The clay-organic material (mainly chaff) ratio is at least $93: 7$ (i.e. 93\% of clayey material and at least $7 \%$ of cereal by-products).

\section{Conclusions}

The results of the plant macroremain studies of the Eneolithic lakeshore settlement Stare gmajne at Ljubljansko barje are presented. Archaeobotanical material was collected with two different sampling methods: 1) systematic surface sampling from the cultural layer, and 2) judgement sampling from the incompletely burnt large loom-weight. When comparing the results, the preservation (taphonomy) and the spectra of plant macroremains diverse greatly, so the results of both studies yield different, but favourable conclusions.
The surface sampled sediment from the cultural layer gives an insight into the plant economy and nutritional habits of the settlers, as well as an insight into the environment and ecological conditions on and around the site. Six crop taxa were recorded. Plants that had been gathered from the woodland, woodland edges and the lake were also important for nutrition. Other non-nutritive seeds/fruits remains of wild flora indicate that the settlement was located close to the lake or a slow-flowing river. Marshy or lakeshore plant species and the ruderals grew nearby or even within the settlement. The remains of woodland plants and plants from woodland edges suggest that the settlers exploited the nearby forest for gathering food, felling trees, pasturing animals and hunting.

The judgement sampled sediment from the loomweight deals primarily with carbonised and semi-carbonised cereal macroremains (mostly chaff) that were preserved inside the loom-weight and were intentionally added to the clay to reinforce the large clayey object. This gives a detailed insight into the cereal cultivation and crop processing habits of the settlers. The deliberate use of cereal by-products was confirmed. The clay-cereal chaff ratio (93:7) was established.

It was possible to compare both studies with regard to the cereal economy. The cereal by-products, which were preserved in two different ways (not carbonised in surface samples $v s$. carbonised in the loomweight), confirm the cultivation of the main crops: emmer, einkorn, and barley. The greater importance of barley is suggested by the surface samples, but the judgement sample does not confirm this. The differential carbonisation and destruction rates of different plant types when exposed to heat (e.g., Boardman, Jones 1990; see the experiment) prevent us from establishing which crop species predominated at the Stare gmajne site.

The investigation of the surface samples yields additional information about the plant economy. The 
settlers' activities and plant gathering, pasturing and fodder collection had an impact on the vegetation in the vicinity of the settlement (also e.g., Andric et. al. 2008; Andrič in prep.).

The judgement sample provides supplementary information about crop husbandry practices, the development stage and the inventiveness of the Eneolithic settlers. According to Marijke van der Veen (1999), the use of chaff can be linked to various scales of production and organisation in the agricultural system. She suggests that different types of use (casual use, intentional local use, use as a commercial commodity) can be broadly correlated with three developmental stages of agricultural production. The intentional local use of cereal by-products as temper suggests that pile dwellers all around the Alps were highly organised and developed as a result of the expansion of crop production and processing.

\section{References}

Anderberg A. L. 1994. Atlas of seeds and small fruits of Northwest-European plant species with morphological descriptions. Part 4: Resedaceae-Umbelliferae. Risbergs Tryckeri AB. Uddevalla.

Andrič M., Kroflič B., Toman M. J., Ogrinc N., Dolenc T., Dobnikar M. and Čermelj B. 2008. Late Quaternary vegetation and hydrological change at Ljubljansko barje (Slovenia). Palaeogeography, Palaeoclimatology, Palaeoeco$\log y$ 270: $150-165$.

Andrič M. (in prep.). Pile dwelling settlement Stare gmajne and the vegetation of Ljubljansko barje in the $4^{\text {th }}$ mill. Cal. BC. In A. Velušček (ed.), in preparation. Opera Instituti Archaeologici Sloveniae. Založba ZRC. Ljubljana.

Bakels C. 1984. Abdrücke von Pflanzenresten aus der Siedlung von Frauenhofen Ried Milchtaschen. Archaeologia Austriaca 68: 47.

Berggren G. 1969. Atlas of Seeds and small fruits of Northwest-European plant species (Sweden, Norway, Denmark, East Fennoscandia and Iceland) with morphological descriptions. Part 2 Cyperaceae. Swedish Natural Science Research Council. Stockholm.

Berggren G. 1981. Atlas of Seeds and small fruits of Nortwest-European plant species (Sweden, Norway, Denmark, East Fennoscandia and Iceland) with morphological descriptions. Part 3 Saliacaceae - Cruciferae. Swedish Natural Science Research Council. Stockholm.

Boardman S., Jones G. 1990. Experiments on the effects of charring on cereal plant components. Journal of Archaeological Science 17: 1-11.

Borojević K. 2006. Terra and silva in the pannonian plain. Opovo agro-gathering in the Late Neolithic. British Archaeological Reports IS 1563. Archaeopress. Oxford.
Bowman A. R. A. 1966. Studies on the heat induced carbonisation of cereal grains. Unpublished undergraduate dissertation. Department of Agricultural Botany. University of Reading. Reading.

Cappers R., Bekker R. M. and Jans J. E. A. 2006. Digitale Zadenatlas van Nederland (Digital Seed Atlas of the Netherlands). Barkhuis Publishing \& Groningen University Library. Groningen.

Čufar K., Velušček A., Tolar T. and Kromer B. 2009. Dendrochronological research at the pile-dwelling settlements Stare gmajne and Blatna Brezovica. In A. Velušček (ed.), Stare gmajne pile-dwelling settlement and its era. Opera Instituti Archaeologici Sloveniae 16. Založba ZRC. Ljubljana: 177-196.

Čufar K., Kromer B., Tolar T. and Velušček A. 2010. Dating of the $4^{\text {th }}$ millennium BC pile-dwelling on Ljubljansko barje, Slovenia. Journal of Archaeological Science 37: 2031-2039.

Čufar K., Tegel W., Merela M., Kromer B. and Velušček A. 2015. Eneolithic pile dwellings south of the Alps precisely dated with tree-ring chronologies from the north. Dendrochronologia 35: 91-98.

Ginder E. 1996. Vojvodjanske seoske kuće od naboja (Village houses of Vojvodina). Kulturno-istorijsko društvo "Proleće na Čenejskim salašima» PČESA. Novi Sad.

Henn T., Jacomet S., Nagy D. U. and Pal R. W. 2015. Desiccated diaspores from building materials: methodological aspects of processing mudbrick for archaeobotanical studies and first results of a study of earth buildings in southwest Hungary. Vegetation History and Archaeobotany 24: 427-440.

Hillman G. C. 1981. Reconstructing crop husbandry practices from charred remains of crops. In R. Mercer (ed.), 
Farming practice in British prehistory. Edinburgh University Press. Edinburgh: 123-162.

1984. Interpretation of archaeological plant remains: the application of ethnographic models from Turkey. In W. A. Van Zeist, W. A. Casparie (eds.), Plants and ancient man. Balkema. Rotterdam: 1-41.

1984a. Traditional husbandry and processing of archaic cereals in recent times: the operations, products and equipment which might feature in Sumerian texts. Part I: the glume wheats. Bulletin Sumerian Agriculture 1: $114-151$.

Hopf M. 1977. Pflanzenreste aus der linearbandkeramischen Siedlung Poigen, Ger.-Bez. Horn, Niederösterreich. In E. Lenneis (ed.), Siedlungsfunde aus Poigen und Frauenhofen bei Horn. Prähist Forsch 8. Horn: 97-99.

1980. Getreideabdrücke in Hüttenlehm von Pulkau. Archaeologia Austriaca 64: 108.

Hosch S., Zibulski P. 2003. The influence of inconsistent wet-sieving procedures on the macroremains concentrations in waterlogged sediments. Journal of Archaeological Science 30: 849-857.

Jacomet S. 2006. Bestimmung von Getreidefunden aus archäologischen Ausgrabungen. Identification of cereal remains from archaeological sites. IPAS, Basel University, Basel. On-line http://ipna.unibas.ch/archbot/pdf/ Cereal_Id_Manual_engl.pdf

Jacomet S., Kreuz A. 1999. Archäobotanik. Verlag Eugen Ulmer. Stuttgart.

Kohler-Schneider M. 2007. Early agriculture and subsistence in Austria: a review of Neolithic plant records. In S. Colledge, J. Conolly (eds.), The origins and spread of domestic plants in southwest Asia and Europe. Left Coast Press. Walnut Creek: 209-220.

Jones G. 1991. Sampling in palaeoethnobotany. In W. van Zeist, K. Wasylikowa and K. Behre (eds.), Progress in Old World Palaeoethnobotany. Balkema. Rotterdam: 53-61.
Tolar T. 2016. Arheobotanika. In M. Andrič, T. Tolar and B. Toškan, Okoljska arheologija in paleoekologija. Založba ZRC. Ljubljana.

Tolar T., Jacomet S., Velušček A. and Čufar K. 2010. Recovery techniques for waterlogged archaeological sediments: a comparison of different treatment methods for samples from Neolithic lake shore settlements. Vegetation History and Archaeobotany 19: 53-67.

Tolar T., Jacomet S., Velušček A. and Čufar K. 2011. Plant economy at a late Neolithic lake dwelling site in Slovenia at the time of the Alpine Iceman. Vegetation History and Archaeobotany 20: 207-222.

Tolar T., Jacomet S. and Velušček A. 2016. Cereal chaff used as a temper in loom-weights: new evidence from a Slovenian Eneolithic pile-dwelling site (ca. $3100 \mathrm{cal} \mathrm{BC})$. Vegetation History and Archaeobotany 25: 291-301.

Van der Veen M. 1999. The economic value of chaff and straw in arid and temperate zones. Vegetation History and Archaeobotany 8: 211-224.

Velušček A. 2009. Koliščarska naselbina Stare gmajne pri Verdu. In A. Velušček (ed.), Stare gmajne pile-dwelling settlement and its era. Opera Instituti Archaeologici Sloveniae 16. Založba ZRC. Ljubljana: 49-122.

(ed.) 2009. Stare gmajne pile-dwelling settlement and its era. Opera Instituti Archaeologici Sloveniae 16. Založba ZRC. Ljubljana.

Velušček A., Čufar K. and Zupančič M. 2009. Prehistoric wooden wheel with an axle from the pile-dwelling Stare gmajne at the Ljubljansko barje. In A. Velušček (ed.), Stare gmajne pile-dwelling settlement and its era. Opera Instituti Archaeologici Sloveniae 16. Založba ZRC. Ljubljana: 197-222.

Watson P. J. 1979. Archaeological ethnography in western Iran. The University of Arizona Press. Tucson. 